\title{
T Lymphocytes in Psoriasis
}

\author{
ERROL PRENS, MD, PhD \\ RENO DEBETS, PhD \\ JOOST HEGMANS, MT
}

$\mathbf{T}$ lymphocytes play an important role in the pathogenesis of psoriasis; however, the main topic of debate today is whether $T$ lymphocytes may be considered as the initiators of psoriasis or as the maintainers of a "psoriatic milieu" responsible for the characteristic dermal and epidermal alterations in psoriasis. According to the latter point of view, $\mathrm{T}$ lymphocytes are recruited to the skin and activated nonspecifically via chemokines, followed by adherence to upregulated adhesion molecules on endothelial cells in lesional skin. We reviewed the literature on T lymphocytes in psoriasis and attempted to delineate their role in the pathogenesis of psoriasis.

\section{T-Cell Infiltrates in Different Stages of the Disease}

\section{Uninvolved Psoriatic Skin}

Some decades ago it was stated that "psoriasis exists as a basic aberration throughout the skin" and that "clinically uninvolved skin of psoriatic patients is not normal." 1 These statements are still valid today, even when immunophenotypic and polymerase chain reaction (PCR) studies on T-lymphocyte subsets in uninvolved psoriatic skin are considered. .,3 $^{3}$ Besides epidermal alterations such as enhanced proliferation and biochemical, enzymatic, and cytokine abnormalities, uninvolved psoriatic skin is further characterized by dilated capillaries and a variable degree of perivascular, perifollicular, and epidermal lymphocytic infiltration..$^{45}$ The different immunoregulatory T-lymphocyte subsets are equally represented, but the absolute numbers of CD4+ and CD8+T lymphocytes are significantly increased., ${ }^{4,5}$ Such alterations are generally not observed in the skin of healthy individuals. Histologically, with respect to the numbers and distribution of $T$ lymphocytes, uninvolved psoriatic skin seems to form an intermediate between normal healthy skin and lesional psoriatic skin. Uninvolved skin of psoriatic patients also contains small numbers of the HLA-DR+/CD1a- sub-

From the Department of Immunology, Erasmus University, and University Hospital Rotterdam-Dijkzigt, Rotterdam, The Netherlands.

Address correspondence to Errol Prens, MD, Department of Immunology, University Hospital Rotterdam-Dijkzigt, Dr. Molewaterplein 40, 3015 GD Rotterdam, The Netherlands. class of antigen-presenting cells (APCs), which have an enhanced capacity to stimulate $T$ cells. ${ }^{6,7}$ Together with local T lymphocytes, these APCs may be involved in the initiation of psoriasis. All alterations in uninvolved skin mentioned above, referred to as prepsoriasis, make it understandable as to why the whole skin of genetically predisposed individuals can develop psoriasis.

\section{Early Psoriatic Macule or Papule}

Extravasation of $\mathrm{CD} 4+\mathrm{T}$ lymphocytes and monocytes is the earliest immunohistologic alteration in newly arising psoriatic lesions. ${ }^{5}$ Some studies indicate that degranulation of resident dermal mast cells may be a primary event. Mast cell products initially induce endothelial cell gaps and activation, perforation of the basement membrane, and the subsequent extravasation of mononuclear cells followed by epidermal changes. ${ }^{8} \mathrm{~T}$ lymphocytes and monocytes are first seen perivascularly, mainly in the papillary tips. ${ }^{9}$ Monocytes migrate toward the basement membrane and remain there lined up in close proximity to epidermal basal cells. ${ }^{10} \mathrm{~T}$ lymphocytes migrate toward and invade the epidermis and induce discrete spongiosis (Plate 6). At this stage, dermal polymorphonuclear neutrophils are scarce. ${ }^{11,12}$ The contributions of $C D 4+$ and CD8 + T lymphocytes are equal, with a CD4/CD8 ratio of approximately $1 .^{4,5} \mathrm{~A}$ further increase in this ratio is observed in cases of rapid evolution into plaque lesions. Based on the observation that the extravasation and subsequent infiltration of $C D 4+/ C D 25+T$ lymphocytes into the epidermis precede the epidermal changes, some authors suggest that $\mathrm{T}$ lymphocytes and monocytes play a key role in the induction of new psoriatic lesions. ${ }^{13}$ Relevant to the early involvement of T lymphocytes is the marked increase in the number of HLA-DR+/CD1adendritic cells and the slight decrease in the number of HLA-DR+/CD1a+ Langerhans cells in the epidermis from early psoriatic skin lesions. ${ }^{5,6}$ In addition, intraepidermal $C D 4+T$ lymphocytes were observed in close apposition to HLA-DR+ dendritic cells, a picture normally seen in contact hypersensitivity skin reactions. ${ }^{14}$

\section{Guttate Psoriatic Lesion}

In the guttate lesion there are sufficient changes that make the histologic diagnosis of psoriasis possible. The infiltrate is more pronounced, there is still a predomi- 
nance of T lymphocytes, and monocytes and neutrophils are now well represented in the infiltrate. ${ }^{15}$ Neutrophils are also seen in the epidermis, especially at sites with evident parakeratosis. ${ }^{16}$

The association between guttate psoriasis and group $A$ $\beta$-hemolytic streptococcal infection is well documented. ${ }^{17}$ Generally, the course of events induced by triggering factors resulting in typical psoriatic lesions remains largely unclear. The poststreptococcal or guttate psoriasis model is an attractive one because of the involvement of a clear antigen. In the latter model, reactivity of antibodies or T-cell receptors (TcRs) to streptococcal antigens, especially $M$ protein, which shares homology with human keratin, is considered to be a conceivable mechanism. ${ }^{18,19}$ This cross-reactive immune response induces local activation of the skin immune system and, finally, psoriatic lesions in individuals with the "psoriatic genotype." A similar mechanism may also occur in acute rheumatic fever ${ }^{20}$ The following observations provide evidence for the induction of guttate psoriasis by group $\mathrm{A} \beta$-hemolytical streptococci: (1) antibodies to streptococcal $M$ proteins cross-reacted with normal and lesional psoriatic $\mathrm{skin}^{21}$; (2) streptococcal antigens induced enhanced proliferation of T lymphocytes from the peripheral blood and skin lesions of patients with guttate and plaque-type lesions ${ }^{18,22}$; (3) these $T$ cells were of the $C D 4+, \operatorname{TcR} \alpha / \beta+$, and memory phenotype and produced helper-T-cell type 1 cytokines such as interleukin-2 (IL2) and interferon $\gamma$ $(\text { IFN- } \gamma)^{22,23}$; (4) local administration of streptococcal antigen induced new psoriatic lesions ${ }^{24}$; and (5) there is a shift of peripheral T cells, similar to streptococcal antigen-specific $T$ cells, expressing TcR $\beta$ chain variable $(V)$ gene segment $2(V \beta 2)$ to dermis and epidermis and, to a lesser extent, of $V \beta 5.1+T$ cells to dermis in patients with guttate and plaque-type psoriasis. ${ }^{23,25}$

\section{Pustular Lesion}

Immunohistologic time course studies on pustular psoriasis are scarce, but some studies on palmoplantar pustulosis are available. Polymorphonuclear neutrophils are the most prominent cells in this form of psoriasis. In the earliest phases, however, neutrophil accumulation is preceded by T-cell infiltration into the epidermis. ${ }^{26,27}$ As in early nonpustular psoriatic lesions, the epidermal $\mathrm{T}$ lymphocytes are $\mathrm{CD} 4+/ \mathrm{CD} 25+$ and are seen in close apposition to epidermal dendrocytes. ${ }^{14}$ Marked attraction of neutrophils forming Munro's microabscesses or spongiform pustules of Kogoj also occurs in plaque-type lesions and has been related to increased local production of IL-8. ${ }^{28,29}$ The latter assumption is questionable because IL-8 is also overexpressed in other cutaneous disorders such as allergic contact dermatitis, lichen planus, and mycosis fungoides (own immunohistochemical observations) in which neutrophils are not prominent or even absent. In all likelihood, a combination of the altered interactions with the psoriatic endothelium and the epi- dermis and the spectrum of locally produced chemoattractants underlies this specific pattern of neutrophil attraction. It may well be that in pustular psoriasis there is further aberration of the altered epidermal cytokine profile. To date, the exact basis for the specific attraction of neutrophils remains unclear.

\section{Plaque-Type Lesion}

In plaque-type lesions the dense inflammatory infiltrate in the dermis is composed of lymphocytes, monocytes, dendrocytes, and polymorphonuclear leukocytes. In the dermis, T lymphocytes are seen perivascularly and at the tips of the elongated papillae. Activated T lymphocytes are regularly observed in the epidermis. The number of intraepidermal $\mathrm{T}$ lymphocytes is highest in psoriasis when compared with other inflammatory skin diseases. Studies by different authors have demonstrated that the epidermal $\mathrm{T}$ lymphocytes are of the helper-inducer or memory type and express the following membrane markers: CD4, CD11a, CD25, CD45RO, CD49d, CD54, Cdw60, HLA-DR, CLA (Plate 7), ${ }^{2,46,6,11,30-32)}$

Based on their cytokine production profile, human $\mathrm{CD} 45 \mathrm{RO}+$ helper $\mathrm{T}$ lymphocytes may be classified into helper T type 0, 1, and 2 lymphocytes (Mossman T. Oral communication, Third International Conference on Cytokines, March 28-30,1994). It was unclear whether in psoriasis the infiltrating lymphocytes belonged to the helper T type 1 or helper T type 2 (IL-4 and IL- 5 producers) subset because little was known about the profile of cytokines produced by $\mathrm{T}$ lymphocytes in situ in psoriatic lesions. Elevated levels of IL-2, soluble IL-2 receptor, IFN- $\gamma$, and IFN- $\gamma$-induced protein-10 $(\gamma$-IP-10) have been reported in psoriatic lesions, whereas IL-4 was never detected. ${ }^{33-35}$ Thus, these data favor a role for helper $T$ type 1 lymphocytes in the pathophysiology of psoriasis. This was recently corroborated by the results of PCR experiments by Uyemura and others for the detection of cytokine mRNA in skin extracts from lesional and nonlesional psoriatic skin and healthy control skin. ${ }^{3}$

\section{Signs of T-Cell Activation in Psoriasis}

Further indirect evidence for the involvement of the cellular immune system has been obtained from blood, serum, suction-blister fluid, and urine and skin tests of psoriatic patients. Peripheral blood of psoriatic patients displays signs of $\mathrm{T}$-cell activation such as an increased number of activated (CD25+/HLA-DR+) T lymphocytes (Table 1$)^{6}$ and elevated levels of soluble IL-2 receptor, soluble CD8, and soluble intercellular adhesion molecule 1 (ICAM-1) and shows increased migratory activity in response to appropriate chemoattractants. ${ }^{36-40}$ These findings merely represent markers for inflammation and are not specific for psoriasis, because elevated levels of serum IL- 2 receptor are also observed in atopic dermatitis, rheumatoid arthritis, and other inflammatory diseases. ${ }^{37}$ Suction-blister fluid from psoriatic plaques contains ele- 
Table 1. Immunophenotyping of Peripheral Blood Mononuclear Cell Samples From Patients With Psoriasis, Control Subjects, and Patients With Allergic Contact Dermatitis (ACD)

\begin{tabular}{|c|c|c|c|}
\hline $\begin{array}{l}\text { Monoclonal } \\
\text { Antibody }\end{array}$ & $\begin{array}{c}\text { Patients } \\
\text { With } \\
\text { Psoriasis } \\
(\mathrm{n}=24)\end{array}$ & $\begin{array}{l}\text { Controls } \\
\text { Subjects } \\
(n=60)\end{array}$ & $\begin{array}{c}\text { Patients } \\
\text { With } \\
A C D \\
(\mathbf{n}=24) \\
\end{array}$ \\
\hline $\mathrm{CD} 20$ & $6.1 \pm 2.5$ & $7.0 \pm 3.7$ & $6.2 \pm 3.6$ \\
\hline $\mathrm{CD3}$ & $57.7 \pm 8.2$ & $59.1 \pm 13.1$ & $61.1 \pm 9.6$ \\
\hline CD4 & $38.2 \pm 6.6$ & $38.4 \pm 10.9$ & $38.1 \pm 9.5$ \\
\hline $\mathrm{CD} 8$ & $20.5 \pm 6.3$ & $20.8 \pm 5.4$ & $23.1 \pm 5.4$ \\
\hline $\mathrm{CD} 4 / \mathrm{CD} 8$ & $2.0 \pm 0.9$ & $2.0 \pm 0.8$ & $1.7 \pm 0.8$ \\
\hline CD14 & $22.6 \pm 8.6$ & $18.9 \pm 8.5$ & $19.1 \pm 7.7$ \\
\hline HLA-DR & $29.3 \pm 8.3$ & $27.5 \pm 8.8$ & $27.6 \pm 8.1$ \\
\hline CD25(IL-2 receptor) & $4.4 \pm 9.7^{*}$ & $0.2 \pm 0.2$ & $1.1 \pm 0.6$ \\
\hline CD71(TFR)† & $4.3 \pm 4.8^{*}$ & $0.5 \pm 0.5$ & $1.7 \pm 1.2$ \\
\hline
\end{tabular}

Note. Results are expressed as the mean percentage $\pm S D$ of monocyte and lymphocyte subsets in PBMC samples from patients with psoriusis, healthy control subjects, and patients woith $A C D$. Clusters of differentiation (CD) are shown.

- $\mathrm{P}<.001$, WT, when compared with the results for healthy control subjects.

t TFR, transferrin receptor.

vated IL-6, IFN- $\gamma$, and IFN- $\alpha$ activity.$^{33,40,41}$ Psoriatic patients with increased IL- 6 levels in blister fluid from plaque-type lesions displayed no increase in IL-6 levels in blister fluid from nonlesional skin and in serum. ${ }^{11}$ This indicates that the IL-6 was locally produced in the psoriatic lesions; however, other studies of patients with severe psoriasis did show elevated serum levels of IL-6, possibly derived from activated peripheral blood mononuclear cells (PBMCs). ${ }^{\mathbf{1 2 , 4 3}}$ Levels of IFN- $\gamma$ and IFN- $\alpha$ are also increased in the sera from psoriatic patients and correlate positively with disease activity. ${ }^{44}$ Immunohistologically, the expression of IFN- $\alpha$ and IFN- $\gamma$ was confined to basal keratinocytes and to stratum corneum and dermal mononuclear cells, respectively. ${ }^{45}$ Lesional $\mathrm{T}$ lymphocytes are to be considered the most likely source of the elevated IFN- $\gamma$ levels because keratinocytes do not produce bioactive IFN- $\gamma,{ }^{46}$ Indeed, in vivo, psoriatic keratinocytes exhibit signs of exposure to IFN- $\gamma$ such as expression of $\gamma$-IP-10 and ICAM-1, but in most cases not HLA-DR. ${ }^{34,47}$ The expression of these molecules partially parallels the elevated levels of IFN- $\gamma$ in psoriatic lesions. The sporadic expression of HLA-DR on psoriatic keratinocytes is remarkable and probably based on the differences in responsiveness to IFN- $y$ between normal and psoriatic keratinocytes. ${ }^{4-50}$ Psoriatic keratinocytes show decreased upregulation of HLA-DR, less inhibition of cell growth, enhanced production of transforming growth factor (TGF- $\alpha$ ), and no downmodulation of their epidermal growth factor (EGF)/TGF- $\alpha$ receptor on stimulation with IFN- $\gamma^{49.50}$ In psoriatic skin the IFN- $\gamma$ receptors are in fact confined to the basal epidermal layers, whereas the IFN- $\gamma$ receptors are distributed throughout the epidermis of normal skin. ${ }^{51}$ The reported induction or exacerbation of psoriasis by recombinant IFN- $\gamma$ and IFN- $\alpha$ stresses their inductive role in this disease. ${ }^{52,53}$

The urine of psoriatic patients contains increased levels of neopterin, a substance indirectly related to $\mathrm{T}$-cell activation. ${ }^{54,55}$ The concentration of neopterin in the urine seems to correlate positively with the disease activity in psoriasis, whereas different antipsoriatic treatments significantly reduce the level of neopterin in the urine. ${ }^{54.55}$

In vivo delayed hypersensitivity skin test reactions to dinitrochlorobenzene (DNCB), a potent sensitizer, seem to be impaired in psoriatic patients. ${ }^{56}$ The impairment appears to be related to the disease activity, because patients free of lesions do not exhibit this impairment. Intradermal tests using purified mycobacterial protein derivative (PPD) and streptokinase/streptodornase partially confirmed the results obtained with DNCB, because 48 hours after skin testing, only the skin reactions to streptokinase/streptodomase differed significantly from those of the controls. ${ }^{56}$ In the same study, it was noted that the reactions to PPD persisted longer in patients with psoriasis, which suggested an impaired ability to switch off cell-mediated immune reactions.

\section{Evidence for Immunopathogenic Mechanisms in Psoriasis}

The potential pathogenic role of bone marrow-derived cells in psoriasis is illustrated by the clearance of longstanding severe psoriasis after allogeneic bone marrow transplantation, ${ }^{57}$ as well as induction of psoriasis in a recipient of HLA-matched bone marrow from an individual with psoriasis. ${ }^{58}$ Moreover, manifestation of psoriasis in a patient without neutrophils and monocytes in the peripheral circulation again indicates a prominent role for T lymphocytes in the initiation of psoriasis. ${ }^{39}$ This case also indicates that neutrophils are not a prerequisite for the initiation of psoriasis. Studies on intravenous administration of anti-CD3/CD4 monoclonal antibodies showed that depletion of circulating $\mathrm{T}$ lymphocytes resulted in the improvement of psoriasis. ${ }^{60}$ Finally, the course of psoriasis is generally characterized by remissions and exacerbations of the disease. A similar course is also often observed in classic autoimmune (skin) diseases. In the latter case, the variation in disease activity is attributed to the imbalances between effector and suppressor mechanisms of the immune system. ${ }^{61}$ Comparable mechanisms may regulate disease activity in psoriasis. In conclusion, these observations indicate that the abnormalities in psoriatic keratinocytes may be triggered by, or are highly dependent on, CD4+ $\mathrm{T}$ lymphocytes and their cytokines and emphasize the importance of immunopathogenic mechanisms in psoriasis. ${ }^{62,63}$

\section{In Vitro Studies on the Function of $T$ Lymphocytes in Psoriasis}

Data on the in vivo situation showing that $T$ lymphocytes are consistently involved in early psoriatic lesions were summarized in the previous paragraphs. These data support the hypothesis that psoriasis is a disease of keratino- 
cyte proliferation induced by $\mathrm{T}$ lymphocytes and $\mathrm{T}$ cellderived proinflammatory agents. ${ }^{13}$ The most relevant data on in vitro $T$ lymphocyte function in psoriasis are presented in the following paragraphs.

\section{Cell-Mediated Immunity}

The data on cell-mediated immunity in psoriasis are conflicting. Early studies reported a decreased proliferative response of PBMCs from psoriatic patients after stimulation with mitogens such as phytohemagglutinin (PHA) and concanavalin A (ConA) ${ }^{64,65}$; however, normal responses to PHA and pokeweed mitogen have also been reported. ${ }^{66} \mathrm{CD} 3$-triggered peripheral T-cell proliferation is decreased, but is enhanced by extracellular matrix (ECM) components. ${ }^{67}$ The autologous mixed-lymphocyte reaction (MLR) appears to be decreased in patients with psoriasis, with the proliferation inversely correlated with disease activity. ${ }^{68}$ The decreased proliferation was attributed to the reduced production of IL- 2 and IFN- $\gamma$ by peripheral blood $\mathrm{T}$ lymphocytes ${ }^{69}$; however, this decreased response to stimuli of psoriatic $T$ cells was not observed in vitro in our studies. ${ }^{6}$ As mentioned, in other articles consistently increased levels of IFN- $\gamma$ and IL-2 receptor in suction-blister fluids and sera from psoriatic patients were reported..$^{33,37,44}$ These inconsistent findings may be related to arbitrary conditions, such as timing of the in vitro testing in relation to disease activity. In vitro testing for drug allergy, for example, has shown that a severe drug eruption is followed by a period of "anergy" during which PBMCs show decreased or no antigen-specific proliferation. Restoration of antigen-specific proliferation in PBMCs depends on clearance of the drug eruption and is usually observed some weeks later. ${ }^{70}$

$\mathrm{T}$ cells from peripheral blood of psoriatic patients, in the absence of added antigen, show a clear proliferative response in vitro to autologous epidermal cells from lesional as well as uninvolved skin..$^{6,71,72}$ Such a reaction is called the autologous mixed epidermal cell- $T$ lymphocyte reaction (MECLR). Increased autologous MECLR is also observed in cutaneous T-cell lymphoma and atopic dermatitis and after 4 MED UVB irradiation of normal skin, ${ }^{73-75}$ In cutaneous $T$-cell lymphoma and atopic dermatitis, the autologous MECLR is increased only when epidermal cells from involved skin are used. ${ }^{73,74}$

\section{Putative Psoriasis-Related Antigen}

At present, it remains unclear whether the MECLR is antigen driven. Nevertheless, the epidermal HLA-DR+ APCs play a central role by presenting antigen (putative psoriasis-related) to autologous T lymphocytes. ${ }^{6,76} \mathrm{Skin}$ infiltrating $\mathrm{T}$ cells in psoriasis may recognize $\mathrm{MHC}$ class II-associated molecules like superantigens or autopeptides present in the MHC groove. ${ }^{77,78}$ As discussed earlier, $M$ proteins of group A $\beta$-hemolytic streptococci or mycobacterial peptides may act as superantigens via molecular mimicry. ${ }^{19}$ Other potential antigens may be persisting viral or retroviral antigens, drugs themselves, or drug-induced MHC class II-associated neoepithelial antigens. ${ }^{76,79,80}$ In fact, alterations in (the glycosylation of) plasma membrane proteins are primary features of the psoriatic keratinocyte. ${ }^{81}$ Although clear evidence has to be provided, these neo-epithelial proteins may be recognized as nonself on recognition by immunoregulatory cells. Examples of these upregulated (keratinocyte-specific) proteins include calgranulins $A$ and $B$, carcinoembryonic antigen, cystatin A, psoriasin, Pso 27, and psoriasis-associated fatty acid-binding protein (PA-FABP) ${ }^{\text {82-84 }}$ This altered protein expression seems to be related to the hyperproliferative state of these cells, inflammatory stimuli or both. ${ }^{82}$ Other "aberrant" membrane markers expressed by psoriatic keratinocytes are squamous cell carcinoma-related antigen, CD13, CD14, CD36, and CD68 ${ }^{85-87}$ Despite the data in favor of an epidermal psoriasis antigen, such an antigen may not be solely confined to the skin. This may explain the occurrence of arthritis in a proportion of the patients.

\section{Accessory Cells}

Analysis of the APC function in the MECLR shows that not the "classic" Langerhans cells (LCs) (HLA-DR+/ CD1at), but HLA-DR+/CD1a- APCs are the principal stimulators of $\mathrm{T}$ cells in this reaction (Fig 1 ). ${ }^{6}$ Lesional keratinocytes do not stimulate $\mathrm{T}$ cells in the MECLR, probably as result of the limited number of HLA-DR+ keratinocytes in psoriatic lesions. ${ }^{88}$ Our own findings indicate that, besides HLA-DR, adhesion molecules such as CD2, CD11a, CD18, CD54, CD58, and membrane-associated IL-1 on psoriatic epidermal cells also fulfill an accessory role in the autologous MECLR (Prens E. Submitted for publication). In normal skin, only one type of epidermal APC - the HLA-DR+, CD1at, Fc- $\gamma$ and $C_{3}$ receptor-bearing $\mathrm{LC}$-predominates. ${ }^{89,90}$ This means that epidermal cell suspensions depleted of HLA-DR+/ $\mathrm{CD} 1 \mathrm{a}+\mathrm{LC}$ are unable to present antigen to autologous $\mathrm{T}$ cells to stimulate allogeneic $T$ cells. ${ }^{91,92}$

Several reports describe the predominance of HLADR+ cells over CD1 + + cells in epidermal cell suspensions from psoriatic lesions (Table 2) ${ }^{6,939,94}$ It is known that cultured LCs lose their CD1a expression and cytoplasmic Birbeck granules, but the expression of HLA-DR is upregulated and their stimulatory capacity is increased. ${ }^{95-97}$ Fresh LCs process and present native antigen more efficiently than cultured LCs, whereas cultured LCs are equally efficient at presenting preprocessed antigen, but superior at stimulating allogeneic $T$ lymphocytes. ${ }^{96,97}$ Cultured LCs exhibit a unique feature that is not shared by fresh LCs, namely, an extraordinary capacity to stimulate syngeneic $T$ lymphocytes. ${ }^{97}$ Thus, fresh and cultured LCs may be considered as the in vitro representatives of their in vivo counterparts, respectively: intraepidermal LCs and LCs that have migrated to the draining lymph nodes (nodal LCs). ${ }^{97}$ Elevated levels of cytokines may 


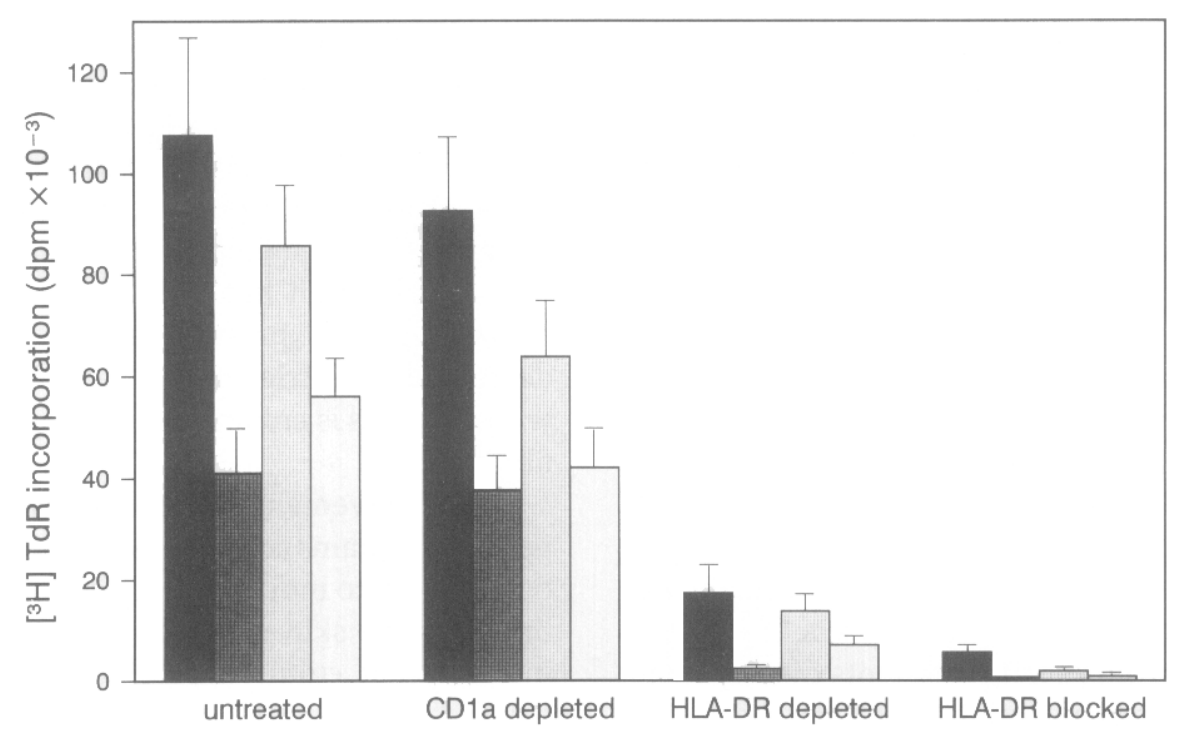

Figure 1. The role of HLA-DR+ and HLA-DR/CD1a+ skin APC subsets in the autologous MECLR. Purified T lymphocytes were cocultured with autologous total epidermal cells (ECs), CD1a depleted ECs, or EC suspensions depleted of CD1a+ and HLA-DR+ cells, all at a concentration of $4 \times 10^{4}$ ECs per well. The cultures were pulsed with tritiated thymidine and harvested 8 hours later. Blocking was performed by addition of dialyzed anti-HLA-DR mAb to the cultures. Filled, bold speckled, fine speckled, and blank bars represent the arithmetic mean $\pm S E M$ dpm of quadruplicate cultures on the day of maximum proliferation of an individual patient. Paired results of four representative patients are shown. Reprinted with permission from Prens et al. ${ }^{6}$

alter the microenvironment in psoriatic lesions in such a way that in vivo lymph node or in vitro culture conditions are stimulated. As the phenotype and some functional characteristics between "cultured" LCs and HLA-DR+/ CD1a- APCs occurring in psoriatic lesions are similar, the latter cell type may be considered as the in vivo equivalent of in vitro "cultured" LCs. ${ }^{98}$ Thus, HLA$\mathrm{DR}+/ \mathrm{CD} 1 \mathrm{a}-\mathrm{APCs}$ in psoriatic lesions probably represent cytokine-activated LCs.

\section{Interference of T Lymphocytes With Stroma and Epidermal Cell Behavior}

Extravasation, (epi)dermal recruitment, and recirculation of $T$ lymphocytes are essential processes for immune surveillance of the skin. Lymphocyte trafficking comprises at

Table 2. Levels of Expression of Activation Markers on Epidermal Cells From Lesional Psoriatic (PP), Uninvolved Psoriatic (PN), and Healthy Control (NN) Skin

\begin{tabular}{lccr}
\hline & \multicolumn{3}{c}{ Percentage Expression } \\
\cline { 2 - 4 } Marker & $P P$ & $P N$ & \multicolumn{1}{c}{$N N$} \\
\hline CD36(OKM5)+ & $23 \pm 12^{*}$ & $0.3 \pm 0.1$ & $0.5 \pm 0.1$ \\
CD54(ICAM-1)+ & $31 \pm 14^{*}$ & $0.6 \pm 0.1$ & $0.5 \pm 0.1$ \\
mlL-1+ & $57 \pm 21^{*}$ & $12 \pm 3^{*}$ & $4 \pm 0.5$ \\
HLA-DR+ & $5.1 \pm 1.6^{*}$ & $1.9 \pm 0.6$ & $1.6 \pm 0.4$ \\
CD1a+ & $1.8 \pm 0.7$ & $1.6 \pm 0.4$ & $1.5 \pm 0.4$ \\
\hline
\end{tabular}

Note. Results are expressed as the mean percentage of positive cells $\pm S D$.

* These figures are slgnificantly higher than those for uninvolved psoriatic skin and /or control epidermal cells. least two components: adhesion and migration. Cellular adhesion is controlled by interactions between lymphocytes and endothelial cells via adhesion molecules. Chemokines, chemoattractants for leukocytes, are responsible for the migration of lymphocytes to sites of inflammation. During cutaneous inflammation, adherence of $T$ lymphocytes to the endothelium is followed by diapedesis and immigration into dermis and, finally, epidermis. The interactions of $T$ lymphocytes with (eip)dermal cells and ECM components, the consequences of these interactions, and their role in the pathogenesis of psoriasis follow.

\section{Interaction of $T$ Lymphocytes With Endothelial Cells}

Adhesion of $T$ lymphocytes to vascular endothelium involves a multistep cascade: (1) initial "rolling" of T lymphocytes on the endothelium via selectin-mediated interactions; (2) activation of T-cell integrins by chemokines or divalent cations, resulting in high-affinity ligand binding; and (3) strong adhesion mediated by T-cell integrins. ${ }^{99}$ Chemokines immobilized by endothelial proteoglycans may regulate the type of infiltrating $T$ cells. A clear example of such a cytokine is macrophage inflammatory protein (MIP) $1 \beta$. This protein preferentially attracts $\mathrm{CD} 4+\mathrm{T}$ cells and potentiates the adhesion of $C D 8+T$ cells to vascular cell adhesion molecule (VCAM) 1 on endothelial cells. ${ }^{100}$ Selective recruitment of $T$-cell subpopulations in to the skin is also evidenced by the interaction between cutaneous lymphocyte-associated antigen (CLA) and Eselectin on endothelial cells. This interaction induces di- 
rectional migration of a unique subset of skin-associated memory $T$ cells to sites of chronic cutaneous inflammation. ${ }^{31,101}$ Once in the skin, the expression of CLA may be upregulated further by transforming growth factor $\beta 1$ (TGF- $\beta 1$ ) and, to a lesser extent, by IL-6, both of which are produced by activated keratinocytes.

Interferon $\gamma$ derived from infiltrating $\mathrm{T}$ cells regulates the expression of E-selectin and production of IL- 6 by endothelial cells. ${ }^{102}$ Vice versa, endothelial cells treated with IFN- $\gamma$ were able to induce antigen-dependent proliferation and cytokine production of helper T type 2 cells, but not helper $\mathrm{T}$ type 1 cells. This implies that endothelial cells, by virtue of their capacity to function as accessory and/or antigen-presenting cells, selectively stimulate the transmigration and function of T-cell subsets. ${ }^{103}$

Peripheral T cells from psoriatic patients display augmented binding to normal endothelium as compared with healthy controls and patients with atopic dermatitis and rheumatic arthritis. ${ }^{32,104}$ This augmented lymphocyte binding is reversible with treatment and clinical improvement. The reverse is also true. Normal $C D 4+T$ cells bind specifically to dermal capillary endothelia in psoriatic plaques, but not in uninvolved psoriatic or normal control skin. ${ }^{32}$ Dermal capillaries in psoriatic skin express elevated levels of ICAM-1 and E-selectin, and preferentially allow the adherence of LFA-1+ and CLAt memory T helper cells as compared with the vessels in normal skin. ${ }^{32}$ Furthermore, in psoriasis, VCAM-1 and endoglin, a new $180-\mathrm{kDa}$ dermal endothelial cell activation antigen, are variably upregulated on dermal endothelium. ${ }^{105,106}$ The activated status of endothelium in psoriasis is further illustrated by the increased expression of (tumor necrosis factor $\alpha$ ) TNF- $\alpha$ and TNF receptor on dermal blood vessels. ${ }^{107}$ Cytokines such as IL-1, IL-6, TNF- $\alpha$, and IFN- $\gamma$ which predominate in the psoriatic (epi)dermal microenvironment are the potential candidates for the upregulation of adhesion molecules. These molecules on psoriatic endothelium have been shown to be less sensitive to the downregulatory effects of TGF- $\beta 1{ }^{108}$ Psoriatic endothelial cells display structural abnormalities that together with an increased adhesiveness for $\mathrm{T}$ lymphocytes facilitate trafficking of these cells.

\section{Interaction of $T$ Lymphocytes With Fibroblasts and Extracellular Matrix Components}

After extravasation, skin-infiltrating $T$ cells encounter dermal constituents like fibroblasts and ECM components. $T$ cell - fibroblast interaction results in a mutual activation and in an increased production of TNF- $\alpha$, IFN$\gamma$, and IL- 6 , with T cell-derived TNF- $\alpha$ being responsible for the upregulation of ICAM-1 on fibroblasts. ${ }^{109}$ Thus, T cells initiate a cell contact-mediated mechanism for selection, accumulation, and retention of mononuclear cells via fibroblast ICAM-1 during cutaneous inflammation. ${ }^{110}$

Interaction of lymphocytes with ECM proteins may induce persistent cytokine or chemokine synthesis and
ECM components are able to maintain tissue inflammation in such a manner. For instance, thrombospondin, a protein that is highly upregulated in inflamed skin, preferentially binds to activated very late activation antigen 4 (VLA-4) and VLA-5 present on memory T cells. ${ }^{111}$ The $\beta 1$ integrin (CD29)-mediated interaction between primed T cells and laminin has been shown to induce persistent cytokine gene expression in mononuclear cells. ${ }^{112}$ The decreased CD3-triggered T-cell proliferation in patients with psoriasis is enhanced by collagen types I and IV and fibronectin. ${ }^{67}$

The involvement of fibroblasts in the pathogenesis of psoriasis remains controversial. Psoriatic fibroblasts have been shown to induce hyperproliferation of normal keratinocytes in a skin-equivalent model. ${ }^{113}$ Our own studies indicate that cultured psoriatic fibroblasts produce increased amounts of biologically active IL-6, a cytokine able to induce keratinocyte and lymphocyte proliferation (Debets R, et al. Manuscript in preparation). This altered IL-6 production by lesional psoriatic fibroblasts is associated with a decreased expression of TNF receptor and an altered expression of platelet-derived growth factor (PDGF) receptor B. ${ }^{114}$ At present, it is not known whether these alterations are of a primary nature or are merely a consequence of cellular activation due to $T$ cellfibroblast interactions. Thus, ECM proteins may be involved in the maintenance of psoriatic lesions.

\section{Interaction of $T$ Lymphocytes With Keratinocytes}

Different studies on the interaction between $T$ cells and keratinocytes indicate that three interactive mechanisms are involved: (1) via soluble cell products (cytokines), (2) via cell - cell contact (direct activation), (3) a combination of both mechanisms. Interactive signaling, autocrine, paracrine, and pleiotropic effects are the hallmarks of these mechanisms. The interaction between $T$ cells and keratinocytes can affect the phenotype and function(s) of both cell types. Illustrative are the observations that, on the one hand, $T$ cells from lesional psoriatic skin release growth factors that induce activation, proliferation, and a "psoriatic phenotype" in cultured keratinocytes. ${ }^{30,115} \mathrm{On}$ the other hand, cytokines released by lesional psoriatic, but not normal, epidermal cells potentiate $T$-cell activation. ${ }^{116}$

T-cell cytokines have clear growth regulatory effects on keratinocytes. Supernatants from unstimulated PBMCs ConA-stimulated PBMCs, and allostimulated purified $\mathrm{T}$ cells are able to effectively induce or maintain keratinocyte proliferation in vitro. ${ }^{117}$ The stronger the $T$ cells were stimulated, the more their supernatants induced keratinocyte proliferation. Not only mixtures of cytokines released by stimulated $\mathrm{T}$ cells, but also single (recombinant) human cytokines may induce or maintain their proliferation. ${ }^{118}$ Although IFN- $\gamma$ has been shown to inhibit the proliferation of keratinocytes in vitro, ${ }^{119}$ an increased keratinocyte proliferation was measured in 
vivo following its local administration. ${ }^{120}$ Other cytokines with keratinocyte growth-inducing capacities are IL-1 and IL-6. ${ }^{42,121}$ Vice versa, keratinocyte-derived IL-6, IL-7, and TNF- $\alpha$ support T-cell growth. ${ }^{122}$ T cell-derived IFN- $\gamma$ induces MHC class II, ICAM-1, and $\gamma$-IP-10 expression on keratinocytes.,34,118 Gamma-IP-10, secreted by activated keratinocytes, is a chemoattractant for monocytes and activated $C D 4+$ and $C D 29+T$ cells and potentiates the adhesion of $\mathrm{T}$ cells to endothelial cells. ${ }^{123}$ Phenotypically altered "activated" keratinocytes acquire the ability to serve as accessory cells for superantigen- or mitogeninduced T-cell proliferation. ${ }^{124}$ Lymphocyte function-associated antigen 1/ICAM-1 interaction is crucial for this accessory function. ${ }^{124}$ The exact role of the CD28 ligands in the accessory cell function of keratinocytes is still unclear. ${ }^{124,125} \mathrm{~T}$-cell epidermotropism depends on keratinocyte-derived chemotactic cytokines such as IL-1, IL-8, TGF- $\beta$, and the eicosanoid leukotriene B4 (LTB4) and keratinocyte adhesion molecules such as E-selectin and the B7/BB-1 molecules, which interact with the T-cell molecules CLA and CD28, respectively. VLA-3+ $T$ cells are able to interact with and to penetrate the epidermal basement membrane via adhesion to epiligrin, a basement membrane component. ${ }^{126}$

Although the data are not always consistent, it is conceivable that $T$ cell -keratinocyte interactions cause several alterations in the expression of cytokines and their receptors on psoriatic epidermal cells. The regulation of IL-1 is clearly abnormal in psoriatic skin; low levels of IL-1 $\alpha$, elevated levels of a nonfunctional IL- $1 \beta$, and an elevated ratio of IL-1 receptor antagonist (IL-1 $\alpha$ ) to IL-1 prevail in extracts of lesional psoriatic skin. ${ }^{127,128}$ Using freshly isolated viable cells, we were able to demonstrate that lesional psoriatic epidermal cells have an enhanced ability to secrete biologically active IL- $1 \beta^{129}$ (Debets R. Submitted). Epidermal cells from lesion-free skin were shown to contain elevated levels of IL- $1 \beta$ mRNA. ${ }^{3}$ These data indicate that keratinocyte-derived IL-1 may play a more important role in the pathogenesis of psoriasis than previously assumed.

Other cytokine abnormalities in psoriatic keratinocytes are increased expression of IL-6, IL-8, Gro- $\alpha$, and TGF- $\alpha$ and overexpression of monocyte chemoattractant protein 1 (MCP-1) mRNA. 22,130-133 Cytokine/growth factor receptors overexpressed in psoriatic epidermis are EGF/TGF- $\alpha$, insulin-like growth factor 1 (IGF-F) and IL4 receptors ${ }^{134,135}$ (Prens E. Submitted). Decreased expression of IL-1 receptor has been observed on psoriatic epidermal cells (Prens E. Submitted).

In summary, the data presented here clearly illustrate that $\mathrm{T}$ cell-keratinocyte interactions in psoriasis are responsible for enhanced bidirectional cellular activation. Minute quantities of cytokines released during these interactions may trigger a cascade of intercellular cytokine signals which induce or boost cutaneous inflammation, or both. Therefore, the identification of the primary signal and its cellular source in psoriasis remains extremely difficult.

\section{Effects of Antipsoriatic Therapies on T Cells}

Potentially effective antipsoriatic drugs may improve psoriasis by influencing the steps that are important in $\mathrm{T}$-cell activation and T-cell trafficking into inflamed tissue. These steps include mechanisms such as reducing chemokines, downmodulating adhesion molecules on endothelial cells and/or keratinocytes, influencing the epidermal cytokine milieu, and inhibiting APC function. If one or more of these steps are interfered with, it is conceivable that also the final goal of such a therapy, namely, the reduction of keratinocyte proliferation and normalization of epidermal architecture, will be achieved. It is now known that the most effective antipsoriatic treatment modalities have marked immunosuppressive or immunomodulatory effects. Especially the observations that cyclosporine $A$ was effective in clearing psoriasis emphasized the role of $T$ lymphocytes and cellmediated immune mechanisms in psoriasis. ${ }^{136-138}$

\section{Anthralin}

Anthralin (Dithranol), a synthetic substitute for chrysarobin, acts primarily as an inhibitor of DNA synthesis and several cytosolic enzymes and by its clear effects on mitochondria and thus on the cellular respiratory system. ${ }^{139}$ Besides the inhibitory effects on DNA synthesis and DNA repair in human lymphocytes, little else is known on the precise effects of anthralin on lymphocytes. Functional studies showed that neutrophil migration is inhibited by therapeutically relevant concentrations of anthralin and that the allogeneic MECLR is inhibited, probably via toxic effects on epidermal Langerhans cells. ${ }^{140}$ Resolution of anthralin-treated psoriatic lesions is accompanied by a slight decrease in the number of epidermal $T$ cells, but not by a decrease in the number of epidermal dendritic cells, ${ }^{141}$

\section{Cyclosporine A}

Cyclosporine $\mathrm{A}(\mathrm{Cy} \mathrm{A})$, a cyclic polypeptide initially used to prevent renal allograft rejection, by coincidence also appeared to improve psoriasis. ${ }^{162}$ In subsequent studies, CyA appeared to inhibit $T$-cell activation and the release of IL-2. ${ }^{143,144}$ This property of CyA formed the basis for establishing its efficacy in psoriasis and other chronic inflammatory diseases in which cell-mediated immune reactions were suspected. Analysis of the literature allows the conclusion that $\mathrm{CyA}$ may improve psoriasis via two different pathways. ${ }^{146}$ The first pathway comprises its inhibitory effects on cells of the inflammatory infiltrate and their soluble products. The second pathway comprises its direct antiproliferative effect on keratinocytes, which is not discussed further as it is beyond the scope of this review. 


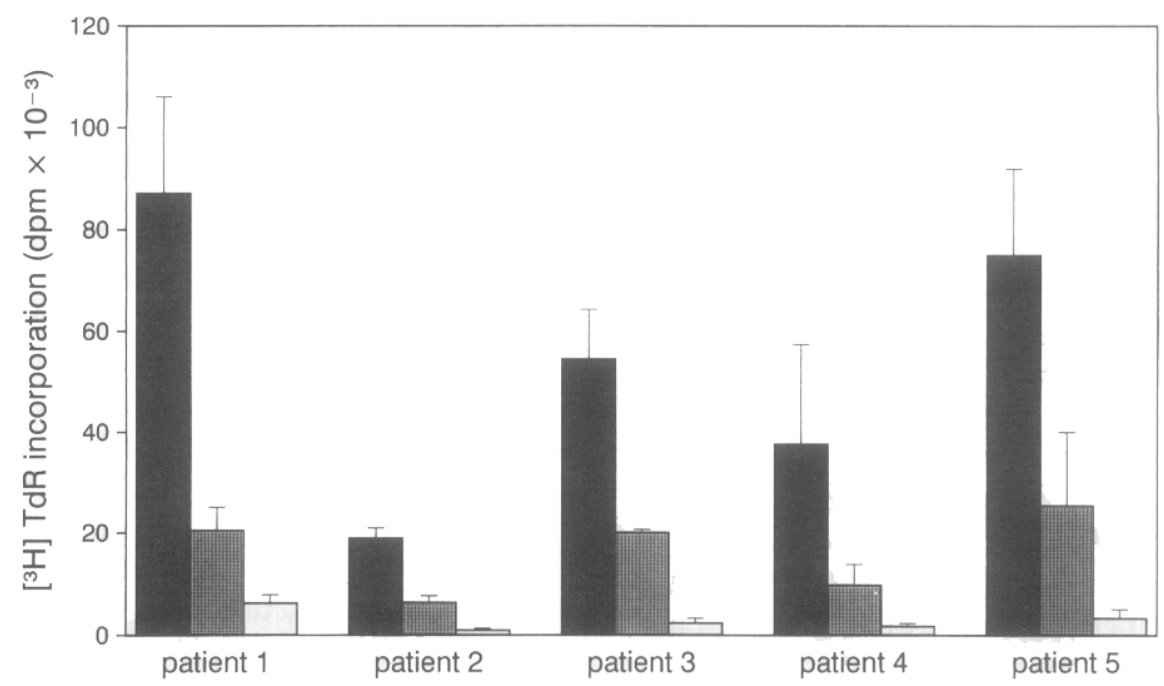

Figure 2. Effect of in vitro preincubation of lesional epidermal cells (ECs) with cyclosporin A (CyA) on the autologous MECLR. Lesional ECs were incubated with 2.5 $\mu \mathrm{g} / \mathrm{mL}$ CyA in RPMI containing $1 \%$ human $A B$ serum for 1 hour at $37^{\circ} \mathrm{C}$. The cells were washed five times with warm RPMI complete medium containing $15 \%$ human $A B$ serum. The cultures were pulsed with tritiated thymidine and harvested 8 hours later. Bars represent the mean \pm SEM dpm of quadruplicate cultures on the day of maximum proliferation. The difference between treated (speckled bars) and untreated (solid bars) $E C s$ is statistically significant $(P<.05$, Wilcoxon signed rank sum test). Blank bars represent the autologous mixed-lymphocyte reaction of each patient. Reprinted with permission from Prens et al. ${ }^{6}$

Besides inhibition of IL-2, CyA is now also known to inhibit transcription of IFN- $\gamma$, IL-3, IL-4, the IL-8/NAPgene family, and TNF- $\alpha$ in T lymphocytes. ${ }^{143-146}$ The downregulation of ICAM- 1 on endothelial and epidermal cells and that of $\gamma$-IP-10 on keratinocytes following CyA treatment are probably secondary to the inhibition of $\mathrm{T}$ cell-derived cytokines. ${ }^{147,148}$ The latter would imply that besides the phenotype of keratinocytes, their proliferation may also be inhibited via decreased release of "growth factors" by T cells. Not only the function, but also the number of $T$ lymphocytes in psoriatic lesions is reduced by $\mathrm{CyA}^{149}$ Immunohistologic studies by different investigators have shown that clinical improvement of psoriasis is accompanied by marked reductions in the number of activated CD25+ and HLA-DR+ epidermal T cells. ${ }^{149,150}$ The prevailing imbalance of epidermal dendritic cell subsets is restored by a significant increase in the number of HLA-DR+/CD1a+ cells after CyA therapy ${ }^{151}$ Although initially debated, there is now agreement that CyA inhibits the stimulatory capacity of epidermal APCs. ${ }^{6,152-154}$ This inhibition is observed in the autologous and allogeneic MECLR following in vitro and in vivo CyA treatment, respectively. ${ }^{6,7,154}$ In the autologous MECLR, under carefully defined in vitro conditions, preincubation of lesional epidermal cells with CyA significantly inhibited the T-cell response (Fig 2), ${ }^{6}$ The synthesis of IL-1, a cytokine essential for the activation of $T$ cells during the presentation of antigen, is inhibited in APCs by CyA treatment. ${ }^{155}$

\section{Glucocorticosteroids}

Glucocorticosteroids have well-known anti-anflammatory effects. Their mode of action, particularly their effects on T lymphocytes, is still incompletely understood. Glucocorticosteroids effectively inhibit DNA synthesis via interaction with the glucocorticoid-responsive element and by modulation of $\mathrm{Ca}^{2+}$ influx into the cell. ${ }^{156}$ Synthesis of inflammatory mediators such as arachidonic acid metabolites is inhibited via upregulation of lipomodulin and phospholipase $\mathrm{A}_{2} \cdot{ }^{157}$ Besides their antiproliferative effects on $T$ cells, corticosteroids may also impair cytokine production by these cells. ${ }^{158}$

More detailed data are available on the effects of corticosteroids on APCs. Antigen-presenting capacity and also the production of IL-1 are clearly inhibited by corticosteroids. ${ }^{159,160}$ In vivo treatment of human, mouse, and guinea pig skin resulted in "depletion" of epidermal APCs. ${ }^{161-163}$ This "depletion" consisted in part of a decrease in the number of HLA-DR+ cells and in part of a downmodulation of surface membrane markers such as CD1a and ATPase. Epidermal cells from a normal skin area that was treated in vivo with a class IV corticosteroid did not induce antigen-specific T-cell proliferation, whereas epidermal cells from an untreated area did so effectively. ${ }^{161,162}$ Treatment of normal skin also resulted in a marked decrease in the number of dermal mast cells. ${ }^{164}$ This, together with the capacity of glucocorticosteroids to inhibit neutrophil accumulation, ${ }^{165}$ may be 
clinically relevant because mast cell degranulation is observed in emerging prepinpoint psoriatic lesions. Topical treatment of psoriatic lesions with a class IV corticosteroid resulted in a rapid decrease in the number of activated epidermal $\mathrm{T}$ cells. ${ }^{141}$ The same treatment also resulted in a gradual decrease in the number of HLA-DR+ dendritic cells, such that even a lower level than in untreated normal skin was reached when the lesions resolved. ${ }^{141}$

\section{Methotrexate}

Methotrexate (MTX) is an antimetabolite that exerts its antipsoriatic effects via antagonism of folic acid and inhibition of thymidylic acid in DNA synthesis. Especially cells in S phase, such as the increased pool of epidermal cells in $S$ phase in psoriatic lesions, are highly susceptible to the antimetabolic effect. ${ }^{166,167}$ Again, not much is known about the mode of action of MTX on T lymphocytes. The effect of MTX on T lymphocytes in S phase will probably be similar, but particularly the weekly cyclic dose scheme makes it difficult to predict the in vivo effects on lymphocytes; however, a major part of epidermal and dermal $T$ lymphocytes in psoriatic lesions are not in $S$ phase. Methotrexate, furthermore, inhibits T-cell activation by APCs in part via inhibition of IL-1 bioactivity. ${ }^{168,169}$ This indicates that probably interference with the epidermal compartment, which always contains some cycling cells, is a more likely target for MTX.

\section{Retinoids}

The well-known "normalizing" effects of synthetic retinoids such as etretinate and acitretin on epithelial differentiation and proliferation are not reviewed here. In this section, we discuss the immunomodulatory effects of retinoids on a variety of hematopoietic cells and nonepithelial tissues. Although the data on the effects of etretinate in humans are rather conflicting, an attempt has been made to summarize them. The inhibition of neutrophil migration was an early event during systemic treatment of psoriasis with etretinate. ${ }^{170,171}$ Regression of psoriatic lesions after treatment with etretinate was accompanied by a distinct increase in the number of dermal and epidermal CD1a+ dendritic cells. ${ }^{172}$ Inhibition of IFN synthesis by natural killer cells and blockage of IFN-induced upregulation of HLA-DR in monocytes and probably epithelial cells have also been observed. ${ }^{173,174}$ Retinoic acid may enhance or inhibit T-cell proliferation depending on the nature of the stimulus. ${ }^{175}$ Skin reactions to DNCB seemed to be enhanced in patients with psoriasis during oral therapy with retinoids. ${ }^{176}$ Interestingly, retinoic acid enhanced epidermal IL-1 production in rats. ${ }^{177}$

\section{Ultraviolet Therapy}

Although ultraviolet radiation (UVR, UVB, as well as PUVA) has clear effects on the human immune system, these effects have been studied best in the animal model. The effects on the skin immune system include inhibition of keratinocyte proliferation, effects on epidermal Langerhans cell function, induction of suppressor cells, and modulation of epidermal cytokine production. ${ }^{178-180} \mathrm{Epi}$ dermal Langerhans cells were significantly depleted in mouse and human skin exposed to UVR. ${ }^{178,179}$ Langerhans cell depletion was accompanied by a decreased ability of mouse skin to become sensitized by contact allergens. ${ }^{179,180}$ Similar results have been obtained in humans, in whom delayed-type hypersensitivity responses were also markedly inhibited by UVR. UVR causes an increase in the synthesis of IL-1 and an IL-1 antagonist by epidermal cells. ${ }^{180-182}$ Cell-mediated reactions may thus be inhibited by antagonism of IL-1 bioactivity by IL-1ra and/ or via induction of prostaglandin $E_{2}$ synthesis in target cells by IL-1. Initial results of UV-photopheresis studies in psoriasis suggest that $\mathrm{T}$-cell proliferation is directly inhibited by photochemotherapy.

Vitamin $D_{3}$ and Analogs

1,25-Dihydroxyvitamin $D_{3}$ (calcitriol) and its synthetic analog calcipotriol have significant immunomodulatory functions. ${ }^{183}$ Vitamin $D_{3}$-deficient rats exhibit impaired immune responses, mainly because of an impaired APC function, that can be restored by supplementation of vitamin $D_{3}{ }^{184}$ The APC function of monocytes and dendritic cells may be inhibited or stimulated by calci(po)triol depending on their stage of differentiation. ${ }^{125}$ The immunomodulatory effects are rather pleiotropic, as they are codependent on the cytokine and hormone milieu, the stage of differentiation of the cells involved, and the nature of eventual costimuli. ${ }^{185}$ For example, the obvious "normalizing" effect of calci(po)triol on keratinocyte differentiation and proliferation is mediated in part by inhibition of the production of $I L-1$ and $\mathrm{IL}-6$ in inflammatory cells and enhancement of the production of TGF- $\beta 1$ and $\beta 2$ by keratinocytes. ${ }^{186-188}$ Besides IL-1 and IL-6, vitamin $D_{3}$ has also been shown to inhibit the production of lymphokines such as IL-2, TNF- $\alpha$, and IFN- $\gamma$ by human mononuclear cells. ${ }^{187}$ The inhibition of IL-2 synthesis by $T$ cells indicates that $T$ cells may be a direct target of vitamin $D_{3}{ }^{187} \mathrm{CD} 45 \mathrm{RO}+$ memory $\mathrm{T}$ cells seem more sensitive to the immunosuppressive effects of this drug than CD45RA+ T cells. ${ }^{189}$ The inhibitory effects on T lymphocytes are further potentiated by simultaneously using 1,25-dihydroxyvitamin $D_{3}$ and CyA. ${ }^{190}$

Calcitriol inhibits IL-8 synthesis in human dermal fibroblasts, keratinocytes, and PBMCs, but not in endothelial cells. ${ }^{191}$ In view of the potent chemotactic properties of IL-8 for T lymphocytes and neutrophils, this may prove to be an important mechanism of action of calci(po)triol in psoriasis.

\section{Conclusions}

Psoriasis may be considered the net outcome of a locally ongoing immune inflammation. The earliest signs in 
emerging lesions are mast cell degranulation and extravasation of $T$ lymphocytes and monocytes. A wide variety of etiologic stimuli such as superantigens, drugs, physical (Koebner), and autoimmune stimuli result in a final common pathway of inflammation. Proinflammatory mediators released by activated T cells, dendritic APCs, and keratinocytes may recruit leukocytes and initiate skin inflammation via interactive signaling between resident and nonresident skin cells and ECM components. The type and the mixture of chemotactic and cell-activating cytokines during the early phases of inflammation dictate the net migratory behavior of the inflammatory cells.

Selectin and integrin interactions in the dermis, the ECM, and the epidermis are crucial to the development and regulation of inflammation in psoriasis. The sequence of events discussed above represents a finely balanced functional network of interactions between cellular constituents of the skin immune system, their soluble products, and the ECM. Imbalances or genetically determined inabilities to produce or tendencies for overproduction of certain molecules of this interactive system form the basis of skin diseases such as psoriasis. One should, however, bear in mind that the cascade of $\mathrm{T}$ cell $\mathrm{ECM}$-keratinocyte interaction-derived proinflammatory cytokines operative in psoriasis under normal conditions (eg, would healing) has beneficial effects for the host.

The majority of the antipsoriatic therapies, apart from their effects on keratinocyte proliferation and differentiation, also interfere in crucial processes such as antigen presentation to $T$ cells, $T$-cell activation/proliferation, and $\mathrm{T}$-cell trafficking into inflamed tissue in psoriasis.

\section{Acknowledgments}

Dr. B. Tank made valuable suggestions and corrected the English. Angela Kooy performed immunohistologic staining of skin sections. Tar van Os and Johan van der Stek prepared the figures. Professor Dr. Theo van Joost and Professor Dr. Robbert Benner assisted in the development of the project.

\section{References}

1. Hell $\mathrm{E}$, Hodgson $\mathrm{C}$. The uptake of ${ }^{3} \mathrm{H}$-thymidine by epidermal cells in normal and psoriatic subjects. Br J Dermatol 1966;78:262-6.

2. De Boer OJ, Van der Loos CM, Hamerlinck et al. Reappraisal of in situ immunophenotypic analysis of psoriasis skin: Interaction of activated HLA-DR ${ }^{+}$immunocompetent cells and endothelial cells is a major feature of psoriatic lesions. Arch Dermatol Res 1994;286:87-96.

3. Uyemura $K$, Yamamura $M$, Fivenson DF, et al. The cytokine network in lesional and lesional-free psoriatic skin is characterized by a T-helper type 1 cell-mediated response. J Invest Dermatol 1993;101:701-5

4. Baker BS, Swain AF, Fry L, et al. Epidermal T lymphocytes and HLA-DR expression in psoriasis. $\mathrm{Br} J$ Dermatol 1984;110:555-64.

5. Placek W, Haftek $M$, Thivolet J. Sequence of changes in psoriatic epidermis. Immunocompetent cell redistribution precedes altered expression of keratinocyte differentiation markers. Acta Derm Venereol (Stockh) 1988;68:369-72.

6. Prens EP, Benne $K$, Van Joost $T$, et al. The autologous mixed epidermal cell- $\mathrm{T}$ lymphocyte reaction is elevated in psoriasis: A crucial role for HLA-DR+ /CD1a- antigen presenting cells. J Invest Dermatol 1991;96:880-7.

7. Cooper KD, Baadsgaard O, Ellis CN, et al. Mechanisms of cyclosporin $\mathrm{A}$ inhibition of antigen presenting activity in uninvolved and lesional psoriatic epidermis. J Invest Dermatol 1990;94:649-56.

8. Brody I. Mast cell degranulation in the evolution of acute eruptive guttate psoriasis. J Invest Dermatol 1984;82:460 4.

9. Brody I. Dermal and epidermal involvement in the evolution of acute eruptive guttate psoriasis vulgaris. J Invest Dermatol 1984;82:465-70.

10. Van den Oord JJ, De Wolf-Peters C. Epithelium-lining machrophages in psoriasis. Br J Dermatol 1994;130:58994.

11. Bos JD, Hulsebosch HJ, Krieg, et al. Immunocompetent cells in psoriasis. In situ immunophenotyping by monoclonal antibodies. Arch Dermatol Res 1983;275:181 -9.

12. Braun-Falco O. The initial psoriatic lesion. In: Farber EM, Cox AJ, editors. Psoriasis. Proceedings of the 2nd international symposium. Stanford: Stanford University Press, 1976: $1-11$.

13. Valdimarsson H, Baker BS, Jonsdottir I, et al. Psoriasis: A disease of abnormal keratinocyte proliferation induced by T lymphocytes. Immunol Today 1986;7:256-9.

14. Heng MCY, Kloss SG. Cell interaction in psoriasis. Arch Dermatol 1985;121:881-7.

15. Schubert C, Schlaak HE, Schröder JM, et al. Ultrastructural sequences of papillary body changes in incipient psoriasis. J Invest Dermatol 1984;82:555.

16. Chowaniec O, Jablonska S, Beutner EH, et al. Earliest clinical and histological changes in psoriasis. Dermatologica 1981;163:42-51.

17. Tefer NR, Chalmers RJG, Whale K, et al. The role of streptococcal infection in the initiation of guttate psoriasis. Arch Dermatol 1992;128:39-42.

18. Baker BS, Powles AV, Malkani AK, et al. Altered cell-mediated immunity to group $A$ haemolytic streptococcal antigens in chronic plaque psoriasis. Br J Dermatol 1991; 125:38-42.

19. McFadden J, Valdimarsson H, Fry L. Cross-reactivity between streptococcal $\mathrm{M}$ surface antigen and human skin. $\mathrm{Br}$ J Dermatol 1991;125:443-7.

20. Baird RW, Bronze MS, Kraus W, et al. Epitopes of group A streptococcal $M$ protein shared with antigens of articular cartilage and synovium. J Immunol 1991;146:3132-7.

21. Swerlick RA, Cunningham MW, Hall NK. Monodonal antibodies cross-reactive with group A streptococci and normal and psoriatic human skin. J Invest Dermatol 1986;87:367-71.

22. Baker BS, Bokth S, Powles A, et al. Group A streptococcal antigen-specific $\mathrm{T}$ lymphocytes in guttate psoriatic lesions. Br J Dermatol 1993;128:493 -9.

23. Lewis HM, Baker BS, Bokth $S$, et al. Restricted T-cell receptor $\mathrm{V}$ beta gene usage in the skin of patients with guttate and chronic plaque psoriasis. Br J Dermatol 1993; 129:514-20. 
24. Rosenberg EW, Noah PW. The Koebner phenomenon and the microbial basis of psoriasis. I Am Acad Dermatol 1988;18:151-8.

25. Tomai MA, Schlievert PM, Kotb M. Distinct T-cell receptor $\mathrm{V} \beta$ gene usage by human $\mathrm{T}$ lymphocytes stimulated with the streptococcal pyrogenic exotoxins and pep M5 protein. Infect Immun 1992;60:701-5.

26. Bacharach-Buhles $M$, Altmeyer P. Pustulosis palmoplantaris. How initial ultrastructural alterations change into vesicles and pustules. Acta Derma Venereol (Stockh) Suppl 1989:95:76-80.

27. Kimura T. Immunological study on the expression of HLA-DR antigen in tonsillar epithelium. Nippon Jibiinkoka Gakkai Kaiho 1992;95:381-90.

28. Fincham NJ, Camp RDR, Gearing AJH, et al. Neutrophil chemoattractant and IL-1-like activity in samples from psoriatic skin lesions. Further characterization. J Immunol 1988;140:4294-9.

29. Gillitzer R, Berger R, Mielke V, et al. Upper keratinocytes of psoriatic lesions express high levels of NAP-1/IL-8 mRNA in situ. J Invest Dermatol 1991;97:73-9.

30. Baadsgaard O, Tong P, Elder JT, et al. UM4D4+ (CDw60) $\mathrm{T}$ cells are compartmentalized into psoriatic skin and release lymphokines that induce a keratinocyte phenotype expressed in psoriatic lesions. I Invest Dermatol 1990; 95:275-82.

31. Picker LJ, Michie SA, Rott LS, et al. A unique phenotype of skin-associated lymphocytes in humans. Preferential expression of the HECA-452 epitope by benign and malignant T cells at cutaneous sites. Am J Pathol 1990; 136:1053-68

32. Chin $\mathrm{YH}$, Falanga V, Taylor J, et al. Adhesion of human helper/memory $\mathrm{T}$ cell subsets to psoriatic dermal endothelium: Mechanisms and modulation. J Invest Dermatol 1990;94:413-7.

33. Takematsu $H$, Tagami $H$. Interleukin 2, soluble interleukin 2 receptor, and interferon-gamma in the suction blister fluids from psoriatic skin. Arch Dermatol Res 1990; 282:149-52.

34. Gottlieb AB, Luster AD, Posnett DN, et al. Detection of a (gamma) interferon-induced protein IP-10 in psoriatic plaques. J Exp Med 1988;168:941-8.

35. Bjercke JR, Livden JK, Degré $M$, et al. Interferon in suction blister fluid from psoriatic lesions. Br J Dermatol 1983; 108:295-9.

36. Gearing AJH, Fincham NJ, Bird CR, et al. Cytokines in skin lesions of psoriasis. Cytokine 1990;2:68-75.

37. Kapp A, Piskorski A, Schopf E. Elevated levels of interleukin 2 receptor in sera of patients with atopic dermatitis and psoriasis. Br J Dermatol 1988;119:707-10.

38. Kapp A. Elevated levels of soluble CD8 antigen in sera of patients with psoriasis - A possible sign of suppressor/ cytotoxic T cell activation. Arch Derematol Res 1990; 282:6-7.

39. Christophers E, Schubert C. Psoriasis. In: Thody AJ, Friedmann PS, editors. Scientific basis of dermatology (a physiological approach). London: Churchill Livingstone, 1986: $151-74$

40. Schopf RE, Naumann S, Rehder M, et al. Soluble intercellular adhesion molecule-1 levels in patients with psoriasis. Br J Dermatol 1993;128:34-7.
41. Prens EP, Benne K, Van Damme J, et al. Interleukin 1 and interleukin 6 in psoriasis. I Invest Dermatol 1990; 95:121S-124S.

42. Grossman RM, Krueger J, Yourish D, et al. Interleukin 6 is expressed in high levels in psoriatic skin and stimulates proliferation of cultured human keratinocytes. Proc Natl Acad Sci USA 1989;86:6367-71.

43. Neuner $P$, Urbanski A, Trautinger $F$, et al. Increased IL-6 production by monocytes and keratinocytes in patients with psoriasis. J Invest Dermatol 1991;97:27 - 33 .

44. Gomi $T$, Shiohara $T$, Munakata $T$, et al. Interleukin 1 alpha, tumor necrosis factor alpha, and interferon gamma in psoriasis. Arch Dermatol 1991;127:827-30.

45. Livden JK, Nilsen R, Bjercke BR, et al. In situ localization of interferons in psoriatic lesions. Arch Dermatol 1989; 281:392-7.

46. Kupper TS. The role of epidermal cytokines. In: Shevach E, Oppenheim J, editors. The role of cells and cytokines in immunity and inflammation. New York: Oxford University Press, 1990: 285 - 305.

47. Griffiths CEM, Voorhees ]], Nickoloff BJ. Characterization of intercellular adhesion molecule-1 and HLA-DR expression in normal and inflamed skin: Modulation by recombinant gamma interferon and tumor necrosis factor. J Am Acad Dermatol 1989;20:617-29.

48. Nickoloff B], Griffiths CEM, Barker JN, et al. The role of adhesion molecules, chemotactic factors, and cytokines in inflammatory and neoplastic skin disease -1990 update. J Invest Dermatol 1990;94:151S-157S.

49. Nickoloff BJ, Mitra RS, Elder JT, et al. Decreased growth inhibition by recombinant gamma interferon is associated with increased transforming growth factor- $\alpha$ production in keratinocytes cultured from psoriatic lesions. Br I Dermatol 1989;121:161-74.

50. Baker BS, Powles AV, Valdimarsson H, et al. An altered response by psoriatic keratinocytes to gamma interferon. Scand J Immunol 1988;28:735-40.

51. Scheynius A, Fransson J, Johansson C, et al. Expression of interferon-gamma receptors in normal and psoriatic skin. J Invest Dermatol 1992;98:255-8.

52. Fierlbeck G, Rassner G, Muller C. Psoriasis induced at the injection site of recombinant interferon gamma. Results of immunohistologic investigations. Arch Dermatol 1990; 126:351-5.

53. Hartmann F, Van Wussow P, Deicher H. Exacerbation of psoriasis during treatment with alpha-interferon. Dtsch Med Wochenschr 1989;114:96-8.

54. Harland CC, Whittaker RP, Barron JL, et al. Increased urine neopterin levels in psoriasis. Br ) Dermatol 1992; 127:453-7.

55. DeRie MA, Hamerlinck F, Bos JD. Neopterin, immune activation, and psoriasis. Lancet 1991;338:1208.

56. McFadden JP, Powles AV, Baker BS, et al. Intradermal antigen tests in psoriasis. Acta Derm Venereol (Stockh) $1989 ; 70: 262-4$.

57. Eedy DJ, Burrows D, Bridges JM, et al. Clearance of severe psoriasis after allogeneic bone marrow transplantation. $\mathrm{Br}$ Med ] 1990;300:908.

58. Gardembas-Pain $M$, Ifrah N, Foussard $C$, et al. Psoriasis after allogeneic bone marrow transplantation. Arch Dermatol 1990;126:1523-25. 
59. Paslin D. Psoriasis without neutrophils. Int J Dermatol 1990;29:37-41.

60. Wernschenker BG, Bass BH, Ebers G. Remission of psoriatic lesions with muromab-CD3 (Orthoclone OKT3) treatment. J Am Acad Dermatol 1989;20:1132-3.

61. Ginzler EM. Clinical manifestations of disease activity, its measurement and associated morbidity in SLE. Curr Opin Rheumatol 1991;3:780-8.

62. Gottlieb AB. Immunologic mechanisms in psoriasis. J Am Acad Dermatol 1988;18:1376-80.

63. Streilein JW. Speculations on the immunopathogenesis of psoriasis: T-cell violation of a keratinocyte sphere of influence. J Invest Dermatol 1990;95:20S-21S.

64. Glinski W, Obalek S, Langner A, et al. Defective function of $\mathrm{T}$ lymphocytes in psoriasis. J Invest Dermatol 1978; 70:105-10

65. Lindholm L, Magnusson BL, Mobacken H. Depressed non-specific lymphocyte reactivity in psoriasis. Arch Dermatol Res 1978;236:121-5.

66. Guihou JJ, Clot J, Meynadier J. T cell defect in psoriasis: Further studies on membrane markers and $T$ cell functions from 60 patients. Arch Dermatol Res 1977;260:163-6.

67. Glinski W, Stepien-Sopniewska B, Majewski S, et al. Alterations of $\mathrm{T}$ cell: Extracellular matrix proteins interactions in psoriasis. Immunol Lett 1993;35:153-7.

68. Terui T, Rokugo M, Aiba S. Autologous mixed lymphocyte reaction is reduced in patients with psoriasis. $\mathrm{Br} J$ Dermatol 1990;123:325-31.

69. Goan SR, Volk HD, Eichhorn I, et al. Differences in interferon-gamma response of psoriatic lymphocytes to stimulation with various mitogens. Biomed Biochim Acta 1986; 45:903-6.

70. Houwerzijl J, De Gast GC, Nater JP, et al. Lymphocyte stimulation tests and patch tests in carbamazepine hypersensitivity. Clin Exp Immunol 1977;29:272-7.

71. Steinmuller D, Zinsmeister AR, Rogers RS. Cellular autoimmunity in psoriasis and lichen planus. J Autoimmun 1988;1:279-98.

72. Schopf RE, Hoffman A, Jung $M$, et al. Stimulation of $T$ cells by autologous mononuclear leukocytes and epidermal cells in psoriasis. Arch Dermatol Res 1986;279: 89-94.

73. Hansen ER, Baadsgaard O, Lisby S, et al. Cutaneous T-cell lymphoma lesional epidermal cells activate autologous $\mathrm{CD}^{+}{ }^{+} \mathrm{T}$ lymphocytes: Involvement of both $\mathrm{CD} 1^{+} \mathrm{OKM}^{+}$ and $\mathrm{CD} 1^{+} \mathrm{OKM} 5^{+}$antigen-presenting cells. J Invest Dermatol 1990;94:485 91.

74. Taylor RS, Baadsgaard $O$, Hammerberg $C$, et al. Hyperstimulatory CD1a+ CD1b + CD36+ Langerhans cells are responsible for increased autologous $\mathrm{T}$ lymphocyte reactivity to lesional epidermal cells of patients with atopic dermatitis. J Immunol 1991;147:3794-802.

75. Baadsgaard O, Fox DA, Cooper KD. Human epidermal cells from ultraviolet light-exposed skin preferentially activate autoreactive $\mathrm{CD4}^{+} 2 \mathrm{H}^{+}$suppressor-inducer lymphocytes and CD8 ${ }^{+}$suppressor/cytotoxic lymphocytes. J Immunol 1988:140:1738-44.

76. Glimcher LH, Longo DL, Green I, et al. Murine syngeneic mixed lymphocyte response. I. Target antigens are self la molecules. J Exp Med 1981;154:1652-70.

77. Nikaein A, Morris L, Phillips C, et al. Characterization of
T-cell clones generated from skin of patients with psoriasis. J Am Acad Dermatol 1993;28:551 -7.

78. Davis MM, Bjorkman PJ. T-cell antigen receptor and T-cell recognition. Nature 1988;334:395-402.

79. Skoven I, Thormann J. Lithium compound treatment and psoriasis. Arch Dermatol 1979;115:1185 - 7.

80. Iversen $O$ J, Rodahl E, Dalen AB. Rabbit antibodies against the major internal protein of a retrovirus-like particle bind to epidermal cells in psoriatic skin. Arch Virol 1985; 86:341-6.

81. DiCicco LM, Fräki JE, Mansbridge JN. The plasma membrane in psoriasis. Int J Dermatol 1987;26:631-8.

82. Madsen $\mathrm{P}$, Rasmussen $\mathrm{HH}$, Leffers $\mathrm{H}$, et al. Molecular cloning, occurrence, and expression of a novel partially secreted protein 'psoriasin' that is highly up-regulated in psoriatic skin. J Invest Dermatol 1991;97:701-12.

83. Siegenthaler G, Hotz R, Chatellard-Gruaz D, et al. Characterization and expression of a novel human fatty acidbinding protein: The epidermal type (E-FABP). Biochem Biophys Res Commun 1993;190:482-7.

84. Hagemeier $\mathrm{HH}$, Bhardwaji R, Grunert F, et al. Carcinoembryonic antigen and related glycoproteins in psoriasis. Pathobiology 1993;61:19-24.

85. Numahara T, Nakashima K, Yamamto S, et al. Significance of squamous cell carcinoma-related antigen in psoriasis and generalized eczema. Preliminary report. Dermatologica 1989;178:73-4.

86. Hunyadi J, Simon M, Kenderessy AS, et al. Expression of monocyte/macrophage markers (CD13, CD14, CD68) on human keratinocytes in healthy and diseased skin. J Dermatol 1993;20:341-5.

87. Barker JN, Markey AC, Allen MH, et al. Keratinocyte expression of OKM5 antigen in inflammatory cutaneous disease. Br J Dermatol 1989;120:613-8.

88. Nickoloff BJ. The cytokine network in psoriasis. Arch Dermatol 1991;127:871-84.

89. Stingl G, Wolff-Schreiner EC, Pichler EJ, et al. Epidermal Langerhans cells bear FC and C3 receptors. Nature 1977; 268:245-6.

90. Klareskog L, Malmnas-Tjernlund U, Forsum U, et al. Epidermal Langerhans cells express la antigens. Nature 1977;268:248-50.

91. Sullivan S, Bergstresser PR, Tigelaar RE, et al. Induction and regulation of contact hypersensitivity by resident, bone marrow derived, dendritic epidermal cells: Langerhans cells and Thy-1+ ${ }^{+}$epidermal cells. J Immunol 1986;137:2460-7.

92. Sontheimer RD. The mixed epidermal cell-lymphocyte reaction. II. Epidermal Langerhans cells are responsible for the enhanced allogeneic lymphocyte-stimulating capacity of normal human epidermal cell suspensions. J Invest Dermatol 1985;85:21S-25S.

93. Baker BS, Lambert S, Powles AV, et al. Epidermal $\mathrm{DR}^{+}$ dendritic cells in inflammatory skin diseases. Acta Derm Venereol (Stockh) 1988;68:209-17.

94. Baadsgaard O, Gupta AK, Taylor RS, et al. Psoriatic epidermal cells demonstrate increased numbers and function of non-Langerhans antigen presenting cells. J Invest Dermatol 1989;92:190-6.

95. Shimada S, Caughman SW, Sharrow SO, et al. Enhanced antigen-presenting capacity of cultured Langerhans cells 
is associated with markedly increased expression of la antigen. J Immunol 1987;139:2551-5.

96. Romani NS, Koide S, Crowley M, et al. Presentation of exogenous protein by dendritic cells to $T$ cell clones. Intact protein is presented best by immature, epidermal Langerhans cells. J Exp Med 1989;169:1169-78.

97. Streilein JW, Grammer SF. In vitro evidence that Langerhans cells can adopt two functionally distinct forms capable of antigen presentation to T lymphocytes. J Immunol 1989;143:3925-33.

98. Demidem A, Taylor JR, Grammer SF, et al. L-lymphocyteactivating properties of epidermal antigen-presenting cells from normal and psoriatic skin: Evidence that psoriatic epidermal antigen-presenting cells resemble cultured normal Langerhans cells. J Invest Dermatol 1991;97: $454-60$.

99. Mackay CR, Imhof BA. Cell adhesion in the immune system. Immunol Today 1993;14:99-102.

100. Tanaka $Y$, Adams DH, Hubscher S, et al. T-cell adhesion induced by proteoglycan-immobilized cytokine MIP-1 beta. Nature 1993;361:15 -6.

101. Picker LJ, Treer JR, Ferguson-Darnell B, et al. Control of lymphocyte recirculation in man. II. Differential regulation of the cutaneous lymphocyte-associated antigen, a tissue-selective homing receptor for skin-homing T cells. I Immunol 1993;150:1122-36.

102. Leeuwenberg JFM, Von Asmuth EJU, Jeunhomme TMAA, et al. IFN- $\gamma$ regulates the expression of the adhesion molecule ELAM-1 and IL- 6 production by human endothelial cells in vitro. J Immunol 1993;145:2110-4.

103. St.-Louis JD, Lederer JA, Lichtman AH. Costimulator deficient antigen presentation by an endothelial cell line induces a non-proliferative $T$ cell activation response without anergy. J Exp Med 1993;178:1597-605.

104. LeRoy F, Brown KA, Greaves MW, et al. Blood mononuclear cells from patients with psoriasis exhibit an enhanced adherence to cultured vascular endothelium. J Invest Dermatol 1991;97:511-6.

105. Groves RW, Ross EL, Barker JN, et al. Vascular cell adhesion molecule-1: Expression in normal and diseased skin and regulation in vivo by interferon gamma. J Am Acad Dermatol 1993;29:62-72.

106. Westphal JR, Willems HW, Schalkwijk CJ, et al. A new 180$\mathrm{kDa}$ dermal endothelial cell activation antigen: In vitro and in situ characteristics. J Invest Dermatol 1993;100:27-34.

107. Kristensen $\mathrm{M}$, Chu CO, Eedy DJ, et al. Localization of tumor necrosis factor-alpha (TNF-alpha) and its receptors in normal and psoriatic skin: Epidermal cells express the $55-\mathrm{kD}$ but not the 75-kD TNF receptor. Clin Exp Immunol 1993;94:354-62.

108. Cai JP, Falaga V, Taylor JR, et al. Transforming growth factor-beta differentially regulates the adhesiveness of normal and psoriatic dermal microvascular endothelial cells for peripheral blood mononuclear cells. J Invest Dermatol 1992;98:405-9.

109. Bombara MP, Webb DL, Conrad P, et al. Cell contact between $T$ cells and synovial fibroblasts causes induction of adhesion molecules and cytokines. I Leukoc Biol 1993;54:399-406.

110. Pawlowski T, Elliott JD, Loh DY, et al. Positive selection of T lymphocytes on fibroblasts. Nature 1993;364:642-5.
111. Yabkowitz R, Dixit VM, Guo N, et al. Activated T-cell adhesion to thrombospondin is mediated by the alpha 4 beta 1 (VLA-4) and alpha 5 beta 1 (VLA-5) integrins. J Immunol 1993;151:149-58.

112. Miyake S, Yagita $H$, Maruyama T, et al. Beta 1 integrinmediated interaction with extracellular matrix proteins regulates cytokine gene expression in synovial fluid cells of rheumatoid arthritis patients. J Exp Med 1993;177: 863-8

113. Saiag P, Coulomb B, Lebreton C, et al. Psoriatic fibroblasts induce hyperproliferation of normal keratinocytes in a skin equivalent model in vitro. Science 1985;230:669-72.

114. Krane JF, Murphy DP, Gottlieb AB, et al. Increased dermal expression of platelet-derived growth factor receptors in growth activated skin wounds and psoriasis. I Invest Dermatol 1991;96:983-6.

115. Strange $P$, Cooper KD, Hansen ER, et al. T-lymphocyte clones initiated from lesional psoriatic skin release growth factors that induce keratinocyte proliferation. I Invest Dermatol 1993;101:695-700.

116. Chang EY, Hammerberg $C$, Fisher GJ, et al. T-cell activation is potentiated by cytokines released by lesional psoriatic, but not normal, epidermis. Arch Dermatol 1992;128: $1479-85$.

117. Hancock GE, Kaplan G, Cohn ZA. Keratinocyte growth regulation by the products of immune cells. J Exp Med 1988;168:1395-402.

118. Krueger JG, Krane JF, Carter DM, et al. Role of growth factors, cytokines and their receptors in the pathogenesis of psoriasis. J Invest Dermatol 1990;94:135S-140S.

119. Nickoloff BJ, Basham TY, Merigan TC, et al. Antiproliferative effects of recombinant (alpha)- and (gamma)-interferons on cultured human keratinocytes. Lab Invest 1984;51:697-701.

120. Barker JN, Goodlad JR, Ross EL, et al. Increased epidermal cell proliferation in normal human skin in vivo following local administration of interferon-gamma. Am J Pathol 1993;142:1091-7.

121. Ristow HJ. A major factor contributing to epidermal proliferation in inflammatory skin diseases appears to be interleukin 1 or a related protein. Proc Natl Acad Sci USA 1987;84:1940-4.

122. Matsue H, Bergstresser PR, Takashima A. Reciprocal cytokine-mediated cellular interactions in mouse epidermis: Promotion of gamma delta T-cell growth by IL-7 and TNF-alpha and inhibition of keratinocyte growth by gamma interferon. I Invest Dermatol 1993;101:543-8.

123. Taub DD, Lloyd AR, Conion $K$, et al. Recombinant human interferon-inducible protein 10 is a chemoattractant for human monocytes and $\mathrm{T}$ lymphocytes and promotes $\mathrm{T}$ cell adhesion to endothelial cells. J Exp Med 1993;177: 1809-14.

124. Nickoloff BJ, Mitra RS, Green J, et al. Accessory cell func tion of keratinocytes for superantigens. Dependence on lymphocyte function-associated antigen-1/intercellular adhesion molecule-1 interaction. I Immunol 1993;150: 2148-59.

125. Gaspari AA, Ferbel B, Chen Z, et al. Accessory and alloantigen-presenting cell functions of $\mathrm{A} 431$ keratinocytes that stably express the B7 antigen. Cell Immunol 1993; 149:291-302. 
126. Wayner EA, Gil SG, Murphy GF, et al. Epiligrin, a component of epithelial basement membranes, is an adhesive ligand for alpha 3 beta 1 positive T lymphocytes. J Cell Biol 1993;121:1141-52.

127. Cooper KD, Hammerberg C, Baadsgaard O, et al. IL-1 activity is reduced in psoriatic skin. Decreased IL-1 alpha and increased non-functional IL-1 beta. I Immunol 1990;144:4593-603.

128. Hammerberg C, Arend WP, Fisher GJ, et al. Interleukin-1 receptor antagonist in normal and psoriatic epidermis. J Clin Invest 1992;90:571-83.

129. Debets $R$, Van Joost $T$, Benner $R$, et al. Psoriatic epidermal cells release elevated levels of immunoreactive and biologically active interleukins 1 and 6: Modulation of corticosteroid treatment. In: Bernard BA, Shroot B, editors. Pharmacology and the skin: From molecular biology to therapeutics. Basel: Karger, 1993;5:158 $\sim 66$.

130. Gillitzer R, Berger R, Mielke V, et al. Upper keratinocytes of psoriatic lesions express high levels of NAP-1/IL-8 mRNA in situ. J Invest Dermatol 1991;97:73-9.

131. Kojima T, Cromie MA, Fisher GJ, et al. Gro-alpha MRNA is selectively overexpressed in psoriatic epidermis and is reduced by cyclosporin $A$ in vivo, but not in cultured keratinocytes. J Invest Dermatol 1993;101:767-72.

132. Gottlieb AB, Chang CK, Posnett DN, et al. Detection of transforming growth $\alpha$ factor in normal, malignant and hyperproliferative human keratinocytes. I Exp Med 1988;167:670-5.

133. Gillitzer $R$, Wolff $K$, Tong $D$, et al. MCP-1 mRNA expression in basal keratinocytes of psoriatic lesions. J Invest Dermatol 1993;101:127-31.

134. Nanney LB, Stoscheck CM, Magid M, et al. Altered epidermal growth factor binding and receptor distribution in psoriasis. J Invest Dermatol 1986;86:260-5.

135. Krane JF, Gottlieb AB, Carter DM, et al. The insulin-like growth factor I receptor is overexpressed in psoriatic epidermis, but is differentially regulated from the epidermal growth factor receptor. J Exp Med 1992;175:1081-90.

136. Van Joost Th, Heule F, Stolz E, et al. Short-term use of cyclosporin A in severe psoriasis. Br J Dermatol 1985; 114:615-20.

137. Ellis CN, Gorsulowsky DC, Hamilton TA, et al. Cyclosporin improves psoriasis in a double-blind study. JAMA 1986;256:1310-6.

138. Griffiths CEM, Powles AV, Leonard JN, et al. Clearance of psoriasis with low dose cyclosporin. Br Med J 1986; 293:731-2.

139. Clark JM, Hanawalt PC. Inhibition of DNA replication and repair by anthralin or danthron in cultured human cells. J Invest Dermatol 1982;79:18- 22.

140. Morhenn VB, Orenerg EK, Kaplan J, et al. Inhibition of LC-mediated immune response by treatment modalities useful in psoriasis. J Invest Dermatol 1983;81:23-8.

141. Baker BS, Swain AF, Griffiths CEM, et al. The effects of topical treatment with steroids or dithranol on epidermal $\mathrm{T}$ lymphocytes and dendritic cells in psoriasis. Scand $\mathrm{J}$ Immunol 1985;23:471-7.

142. Mueller W, Hermann B. Cyclosporin A for psoriasis. N Engl J Med 1979;301:555.

143. Herold KC, Lancki DW, Moldwin RL, et al. Immunosuppressive effects of cyclosporin A on cloned T cells. J Immunol 1986;136:1315-21.
144. Elliot JF, Lin Y, Mizel SB, et al. Induction of interleukin-2 messenger mRNA inhibited by cyclosporin $A$. Science 1984;226:1439-41.

145. Wong RL, Winslow M, Cooper KD. The mechanisms of action of cyclosporin $A$ in the treatment of psoriasis. Immunol Today 1993;14:69-74.

146. Zipfel PF, Bialonski A, Skerka C. Induction of members of the IL-8/NAP-1 gene family in human T lymphocytes is suppressed by cyclosporin A. Biochem Biophys Res Commun 1991;181:179-83.

147. Gottlieb AB, Grossmann RM, Khandke L, et al. Studies on the effect of cyclosporin in psoriasis in vivo: Combined effects on activated $T$ lymphocytes ad epidermal regenerative maturation. J Invest Dermatol 1992;98:302-9.

148. Horrocks C, Duncan JI, Oliver AM. Adhesion molecule expression in psoriatic skin lesions and the influence of cyclosporin A. Clin Exp Immunol 1991;84:157-62.

149. Gupta AK, Baadsgaard O, Ellis $\mathrm{CN}$, et al. Lymphocytes and macrophages of the epidermis and dermis in lesional psoriatic skin, but not epidermal Langerhans cells are depleted by treatment with cyclosporin A. Arch Dermatol Res 1989;281:219-26.

150. Horrocks C, Duncan JI, Sewell HF, et al. Differential effects of cyclosporin A on Langerhans cells and regulatory T cell populations in severe psoriasis: An immunohistochemical and flow cytometric analysis. J Autoimmun 1990;3:559-70.

151. Baker BS, Griffiths CEM, Lambert S, et al. The effects of cyclosporin $A$ on $T$ lymphocyte and dendritic cell subpopulations in psoriasis. Br J Dermatol 1987;116:503-10.

152. Furue $M, K a t z S$. The effect of cyclosporine on epidermal cells. I. Cyclosporine inhibits accessory cell functions of epidermal Langerhans cells in vitro. J Immunol 1988; 140:4139-43.

153. Roberts MS, Knight SC. Low-dose immunosuppression by cyclosporine operating via antigen-presenting dendritic cells. Transplantation 1990;50:91-5.

154. Dupuy $P$, Bagot $M$, Michel $L$, et al. Cyclosporin A inhibits the antigen-presenting functions of freshly isolated human Langerhans cells in vitro. J Invest Dermatol 1991; 96:408-13.

155. Wasik MA, Belle DI. Induction of macrophage interleukin-1 expression by $T$-cell dependent and $T$-cell independent pathways is inhibited by CsA. Clin Immunol Immunopathol 1989;52:331-40.

156. DuVivier A, Stoughton RB. Tachypylaxis to the action of topically applied corticosteroids. Arch Dermatol 1982; 111:581.

157. Hammerstrom S, Hambert M, Duell E, et al. Glucocorticoid in inflammatory proliferative skin disease reduces arachidonic hydroxyeicostetraenoic acids. Science 1977; 197:994.

158. Goulding NJ, Guyre PM. Regulation of inflammation by lipocortin 1. Immunol Today 1992;13:295-7.

159. Belsito DV, Flotte TJ, Lim HW, et al. Effect of glucocorticosteroids on epidermal Langerhans cells. J Exp Med 1982;155:291 - 4 .

160. Snyder DS, Unanue ER, Corticosteroids inhibit murine macrophage la expression and interleukin 1 production. J Immunol 1982;129:1803 -8.

161. Prens EP, Benne K, Geursen-Reitsma AM, et al. Effects of topically applied glucocorticosteroids on patch test re- 
sponses and recruitment of inflammatory cells in allergic contact dermatitis. Agents Actions 1989;6:125-8.

162. Ashwort J, Booker J, Breatnach SM. Effects of topically applied corticosteroid therapy on Langerhans cell antigen presenting function in human skin. Br J Dermatol 1988;118:457 - 70.

163. Aberer W, Stingl G, Pogantsch S. Effect of glucocorticoids on epidermal cell-induced immune responses. J Immunol 1984;133:792-9.

164. Lavker RM, Schechter NM. Cutaneous mast cell depletion results from topical corticosteroid usage. J Immunol 1985;135:2368-73.

165. Boggs DR, Athens JW, Cartwright GE, et al. The effect of adrenal glucocorticosteroids upon the cellular composition of inflammatory exudates. Am J Pathol 1964;44: 763-6.

166. Edmunson WF, Guy WB. Treatment of psoriasis with folic acid antagonist. Arch Dermatol 1958;78:200-3.

167. Weinstein GD, Goldfaden G, Frost P, Methotrexate: Mechanism of action on DNA synthesis in psoriasis. Arch Dermatol 1971;104:236-43.

168. Chang DM, Baptiste P, Schur PH. The effect of antirheumatic drugs on interleukin 1 (IL-1) activity and IL-1 and IL-1 inhibitor production by human monocytes. J Rheumatol 1990;17:1148-57.

169. Segal $R$, Mozes $E$, Yaron $M$, et al. The effects of methotrexate on the production and activity of interleukin-1. Arthritis Rheum 1989:32:370-7.

170. Tsamboas D, Orfanos CE. Ultrastructural evidence suggesting an immunomodulatory activity of oral retinoids. Its effects on dermal components in psoriasis. Br J Dermatol 1981;104:37-45.

171. Ellis CN, Kang S, Grekin RC, et al. Etritinate therapy reduces polymorphonuclear leukocyte chemotaxis enhancing properties of psoriatic serum. J Am Acad Dermatol $1985 ; 13: 437-43$.

172. Guzman-de Fleury M, Tapia FJ, Soto J, et al. Density of epidermal Langerhans cells in psoriasis patients treated with an aromatic retinoid (RO 10-9359). An immunoperoxidase study using anti-T6 and anti-la monoclonal antibodies. Histol Histopathol 1986;1:227-34.

173. Abb J, Abb H, Deinhardt F. Effect of retinoic acid on the spontaneous and interferon-induced activity of human natural killer cells. Int J Cancer 1982;30:307-10.

174. Rhodes J, Stokes P. Interferon-induced changes in the monocyte membrane. Irhibition by retinol and retinoic acid. Immunology 1982;45:531-6.

175. Abb J, Deinhardt F. Retinoids inhibit the mitogenic activity of tumour-promoting phorbol esters on human lymphocytes. Int I Cancer 1981;25:267-71.

176. Fulton RA, Souteyrand $P$, Thivolet $]$. Influence of retinoid Ro 10-9395 on cell-mediated immunity in vivo. Dermatologica 1982;165:568-672.

177. Schmitt A, Hauser C, Didierjean L, et al. Systemic administration of etretin increases epidermal interleukin 1 in the rat. Br I Dermatol 1987;116:615-22.
178. Pullman H, Galosi A, Jakobeit $C_{\text {, }}$ et al. Effects of selected ultraviolet phototherapy (SUP) and local PUVA treatment on DNA synthesis in guinea pig skin. Arch Dermatol Res 1980;267:37.

179. Toews GB, Bergstresser PR, Streilein JW. Epidermal Langerhans cell density determines whether contact hypersensitivity or unresponsiveness follows skin painting with DNFB. J Immunol 1980;124:445-53.

180. Ashwort J, Kahn MC, Breatnach SM. PUVA therapy decreases HLA-DR ${ }^{+}$CD1a ${ }^{+}$Langerhans cells and epidermal cell antigen-presenting capacity in human skin, but flow cytometrically-sorted residual $\mathrm{HLA}-\mathrm{DR}^{+} \mathrm{CD} \mathrm{a}^{+}$Langerhans cells exhibit normal alloantigen-presenting function. Br J Dermatol 1989;120:329 - 39

181. Schwarz T, Urbanska A, Gschnait F, et al. UV-irradiated epidermal cells produce a specific inhibitor of interleukin 1 activity. J Immunol 1987;138:1457-63

182. Kupper TS, Chua AO, Flood $\mathrm{P}$, et al. Interleukin 1 gene expression in cultured human keratinocyte is augmented by ultraviolet irradiation. J Clin Invest 1987;90:430-6.

183. Bagot $M$, Charue $D$, Lescs MC, et al. Immunosuppressive effects of 1,25-dihydroxyvitamin $D_{3}$ and its analogue calcipotriol on epidermal cells. Br J Dermatol 1994;130: 424-31.

184. Wientroub S, Winter CC, Wahl SM, et al. Effect of vitamin $D$ deficiency on macrophage and lymphocyte function in the rat. Calcif Tissue int 1989;44:125-30.

185. Hustmeyer FG, Girasole G, Manolagas SC. Signal-dependent pleiotropic regulation of lymphocyte proliferation ad cytokine production by 1,25 -dihydroxyvitamin $D_{3}$ : Potent modulation of the hormonal effects by phorbol esters. Immunology 1992;77:520-6.

186. Koli $K$, Keski OJ. Vitamin $D_{3}$ and calcipotriol enhance the secretion of transforming growth factor beta- 1 and beta- 2 in cultured murine keratinocytes. Growth Factors 1993; 8:153-63.

187. Muller K, Odum N, Bendtzen K. 1,25-Dihydroxyvitamin $D_{3}$ selectively reduces interleukin-2 levels and proliferation of human $I$ cell lines in vitro. Immunol Lett 1993;35:177-82.

188. Oxholm A, Oxholm P, Staberg B, et al. Expression of interleukin-6-like molecules and tumour necrosis factor after topical treatment of psoriasis with a new vitamin $D$ analogue (MC 903). Acta Derm Venereol (Stockh) 1989; 69:385-90.

189. Muller K, Bendtzen K. Inhibition of human T lymphocyte proliferation and cytokine production by 1,25-dihydroxyvitamin $\mathrm{D}_{3}$. Differential effects on CD45RA ${ }^{+}$and CD45RO ${ }^{+}$cells. Autoimmunity 1992;14:37-43.

190. Gepner P, Amor B, Fournier C. 1,25-dihydroxyvitamin $D_{3}$ potentiates the in vitro inhibitory effects of cyclosporin $A$ on $T$ cells from rheumatoid arthritis patients. Arthritis Rheum 1989;32:31-6.

191. Larsen $C G$, Kristensen $M$, Paludan $K$, et al. $1,25(\mathrm{OH})_{2} D_{3}$ is a potent regulator of interleukin-8 expression and production. Biochem Biophys Res Commun 1991;176:1020-6. 